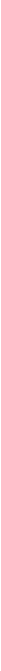

\title{
Das Ende der Evolution - The End of Evolution
}

\author{
Authors: Matthias Glaubrecht \\ Submitted: $\quad$ 18. April 2021 \\ Published: $\quad$ 19. April 2021 \\ Volume: 8 \\ Issue: 2 \\ Affiliation: Katholische Akadamie, Freiburg, Germany \\ Languages: \\ Keywords: \\ Categories: \\ German \\ Evolution, End, Biodiversity, Humans, Planet \\ Humanities, Social Sciences and Law, Life Sciences \\ DOI: $\quad$ 10.17160/josha.8.2.752
}

\section{Abstract:}

The rapid disappearance of biodiversity and the influence of humans. Many scientific studies show: We have been experiencing massive species extinction worldwide for several decades. And it's man-made. The biodiversity of our planet is in danger, with far-reaching and unforeseeable consequences for nature and humans. The decline in biodiversity is just not as visible as climate change, for example. Nevertheless, it is high time to take countermeasures, in both political and private life.

\section{JOSHA Joumal os stamease Humanities and Arts}




\title{
Das Ende der Evolution - The End of Evolution
}

\author{
Professor Dr. Matthias Glaubrecht
}

Vortragsreihe der Musella Stiftung, Katholische Akademie, Freiburg zum Thema "Mensch und Schöpfung".

\section{Abstract}

The rapid disappearance of biodiversity and the influence of humans. Many scientific studies show: We have been experiencing massive species extinction worldwide for several decades. And it's man-made. The biodiversity of our planet is in danger, with far-reaching and unforeseeable consequences for nature and humans. The decline in biodiversity is just not as visible as climate change, for example. Nevertheless, it is high time to take countermeasures, in both political and private life.

https://youtu.be/NTiXIrJvwTk 
Journal of Science, Humanities and Arts

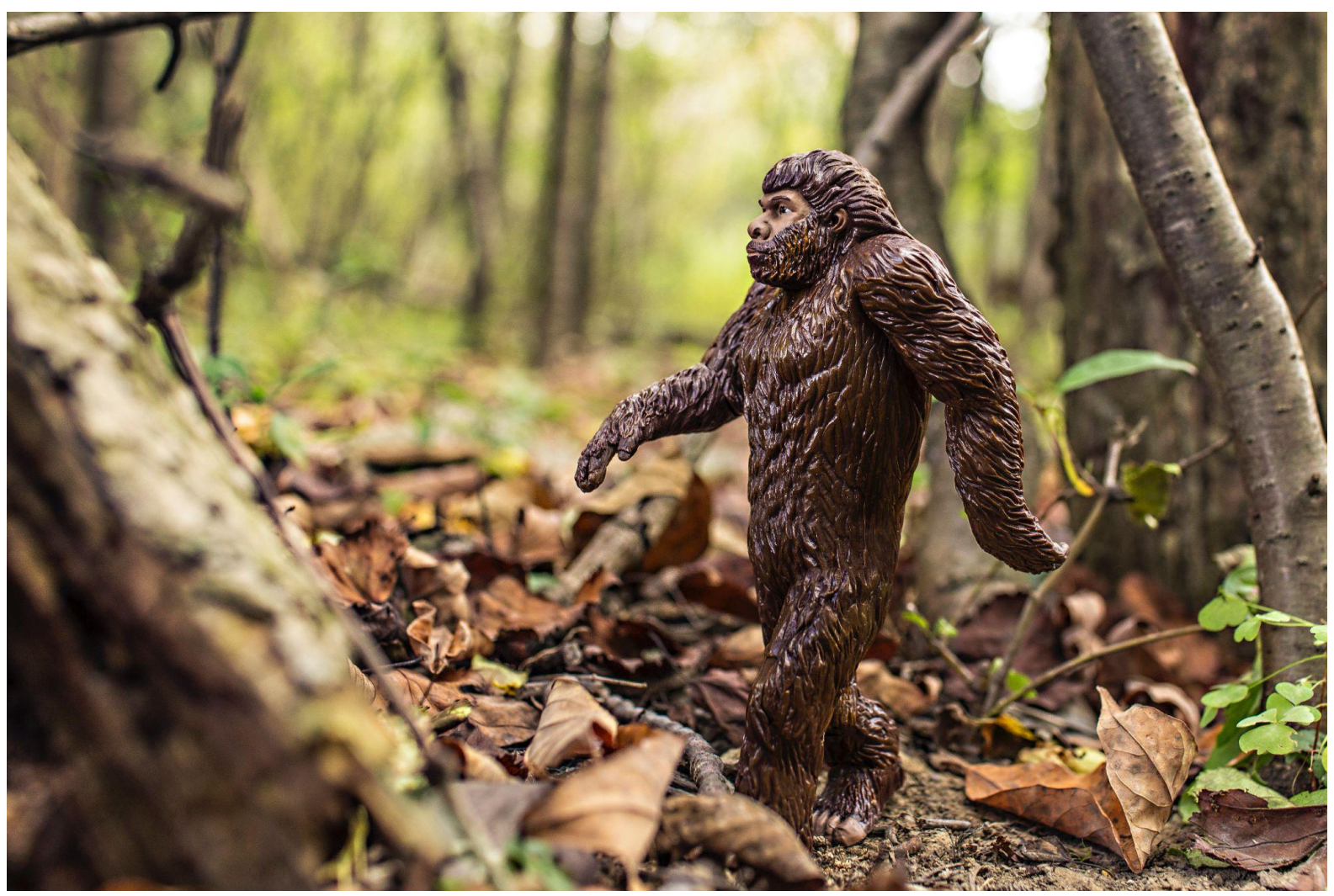

Das rapide Verschwinden der Artenvielfalt und der Einfluss des Menschen. Viele wissenschaftlichen Untersuchungen zeigen es: Wir erleben seit einigen Jahrzehnten ein massives Artensterben weltweit. Und es ist menschengemacht. Die Biodiversität unseres Planeten ist in Gefahr, mit weitreichenden und unabsehbaren Folgen für Natur und Mensch. Der Rückgang der Artenvielfalt ist nur noch nicht so sichtbar, wie etwa der Klimawandel. Gleichwohl ist es höchste Zeit, Gegenmaßnahmen einzuleiten, im politischen wie im privaten Leben.

Diese Auffassung vertrat der Hamburger Zoologe Prof. Dr. Matthias Glaubrecht bei seinem Online-Vortrag »Das Ende der Evolution« am 27. Januar. Und er konnte seine These mit einer Vielzahl an Fakten und wissenschaftlichen Studien untermauern, die er sehr anschaulich darzubieten verstand, so dass auch Nicht-Expert*innen gut folgen konnten. Die anschließende Diskussion vertiefte die evolutionsbiologischen, sozial-ethischen, religiösen und politischen Dimensionen und Hintergründe der Problematik und zeigte auf, dass es höchste Zeit, aber noch nicht zu spät ist. Am Ende entstand auf Nachfrage ein kurzer politischer Forderungs-Katalog Glaubrechts mit den wichtigsten Maßnahmen.

Der Abend stand in der Reihe »Mensch und Schöpfung « und wurde von der Katholischen Akademie Freiburg und der Musella-Stiftung für eine sozial-ökologische Zukunft gemeinsam verantwortet. Vortrag und Diskussion können Sie hier anschauen: 